\title{
Arbuscular mycorrhizal fungi shift competitive relationships among crop and weed species
}

\author{
Hideliza Daisog • Cristiana Sbrana • \\ Caterina Cristani • Anna-Camilla Moonen • \\ Manuela Giovannetti • Paolo Bàrberi
}

Received: 28 June 2011 / Accepted: 16 October 2011

(C) Springer Science+Business Media B.V. 2011

\begin{abstract}
Aims Arbuscular mycorrhizal (AM) symbioses affect plant competitive relationships within and among species and may be involved in the interactions among agricultural weed species and crops, depending on their mycorrhizal status. In this work, the impact of native AM fungi (AMF) on maize-weed(s) and weed-weed competitive relationships was assessed, using Solanum nigrum and Chenopodium album as model host and non-host weeds, respectively.

Methods Growth performance, nutrient use and competitive ability of crop and weed species were assessed in the pure stand and in different model plant communities of host and non-host species.
\end{abstract}

Responsible Editor: Hans Lambers.

H. Daisog • A.-C. Moonen • P. Bàrberi

Institute of Life Sciences, Scuola Superiore Sant'Anna, Piazza Martiri della Libertà 33,

56127 Pisa, Italy

C. Sbrana

CNR, Institute of Biology and Agrobiotechnology,

UOS Pisa,

Via del Borghetto 80,

56124 Pisa, Italy

C. Cristani $\cdot$ M. Giovannetti $(\bowtie)$

Department of Crop Plant Biology, University of Pisa,

Via del Borghetto 80,

56124 Pisa, Italy

e-mail:mgiova@agr.unipi.it
Results Results showed that maize performance decrease was more severe when grown with $C$. album than with $S$. nigrum. Differential responses to AMF occurred in the two weed species tested: mycorrhizal $S$. nigrum showed reduced biomass and $\mathrm{N}$ uptake when grown in competition with $C$. album. The negative performances observed when mycorrhizal $S$. nigrum grew in competition with $C$. album corresponded to $C$. album larger biomass production and $\mathrm{N}$ uptake.

Conclusions Results showed that AMF are able to alter the competitive relationships between cooccurring plant species differing in their mycorrhizal status (host/non-host), thus representing key soil organisms to be taken into account in sustainable weed management strategies.

Keywords Arbuscular mycorrhizal fungi · Zea mays . Chenopodium album . Solanum nigrum . Sustainable weed management $\cdot$ Non-host plants

\section{Introduction}

Co-occurring plant species interact with each other and compete for growth limiting resources such as sunlight, water and nutrients. The outcome of these complex interactions may be affected by soil microbes, in particular when involved in pathogenic and mutualistic associations (Van der Putten and 
Peters 1997; Smith and Read 2008). Arbuscular mycorrhizal (AM) fungi (AMF) are beneficial soil borne symbionts (phylum Glomeromycota) living in the roots of about $80 \%$ of land plant species, including most agricultural crops and weeds (Schussler et al. 2001). AMF play a major role in plant nutrition, absorbing and translocating mineral nutrients, such as $\mathrm{P}, \mathrm{N}, \mathrm{Zn}$ and $\mathrm{Cu}$, to the host cells (Smith and Read 2008) by means of large extraradical mycelial networks spreading from mycorrhizal roots into the soil (Giovannetti et al. 2001, 2004).

Different studies have shown that AMF colonisation may affect plant performance and competitive relationships within and among co-occurring plant species (Eissenstat and Newman 1990; Hamel et al. 1992; Hartnett et al. 1993; Moora and Zobel 1996; Rejon et al. 1997; Scheublin et al. 2007; SchroederMoreno and Janos 2008). AMF effects on plant competitive relationships varied depending on the responsiveness of plant species to fungal colonization (Watkinson and Freckleton 1997). Accordingly, plant benefits were largest in the most responsive plants (Hartnett et al. 1993; West 1996; Scheublin et al. 2007), although they were reduced at high $P$ availability and high plant density (Johnson 1998; Schroeder-Moreno and Janos 2008).

Agricultural weed species, including either mycorrhizal and non- or weakly mycorrhizal plants, varied in their responses to AMF, since mycorrhizal symbioses induced plant growth responses in the majority of host plant-fungus combinations, whereas no responses or negative performances were reported when non-host plants were challenged with AMF (Vatovec et al. 2005). In studies involving individual plant species, i.e. in the absence of competition, AMF reduced growth of non-host weeds (Francis and Read 1995; Muthukumar et al. 1997; Johnson 1998) while produced positive growth responses in host weeds (Koide and Lu 1992, 1995; Heppell et al. 1998; Vatovec et al. 2005; Ayres et al. 2006). Interestingly, in mixed cultures of a host crop and non-host weeds, Rinaudo et al. (2009) reported a reduction of total weed biomass in the presence of AMF.

Since most studies investigating AMF impact on plant competition analysed only host plants, poor knowledge is available on the competitive relationships among non-host plant species or between host and non-host plants. Furthermore, inclusion of crop plants in competitive studies could be very important, considering that weeds can severely affect crop productivity. In agroecosystems, crops and weeds of different mycorrhizal status are likely to co-exist, thus the role of AMF in crop-weed or weed-weed competition might be significant, especially in sustainable, low-input agriculture. Accordingly, knowledge on AMF/weeds relationships may provide important basic information to design innovative, ecologically-based weed management systems relying on reduced use of external inputs.

This work investigated the impact of AMF on maize-weed(s) and weed-weed competitive relationships under controlled conditions, by using Solanum nigrum and Chenopodium album as model host and non-host weeds, respectively. In particular, we assessed growth performance, nutrient use, mycorrhizal benefits and competitive ability both in the pure stand and in different model plant communities of host and non-host species.

\section{Materials and methods}

Plant material

Zea mays L. (cv. Arzano) was used as mycorrhizal crop. Chenopodium album L. and Solanum nigrum L. were used as AMF non-host and host plant species, respectively, since they are two of the most problematic weeds often associated with maize (Bárberi and Mazzoncini 2001; Davis et al. 2005). Seeds of each weed species were purchased from the Herbiseed company (www.herbiseed.com).

\section{Experimental design}

A glasshouse pot experiment was laid out according to a randomised complete block design with two AMF treatments (mycorrhizal presence, $\mathrm{AMF}^{+}$and mycorrhizal absence, $\mathrm{AMF}^{-}$) and seven plant competition treatments, including any mono-, bi- or trispecific combinations for each AMF treatment: (1) $Z$. mays L. alone (M); (2) C. album L. alone (C); (3) $S$. nigrum L. alone $(\mathrm{S})$; (4) Z. mays + C. album $(\mathrm{M}+\mathrm{C})$; (5) Z. mays + S. nigrum $(\mathrm{M}+\mathrm{S})$; (6) Z. mays $+C$. album + S. nigrum $(\mathrm{M}+\mathrm{C}+\mathrm{S}) ;(7)$ C. album $+S$. 
nigrum $(\mathrm{C}+\mathrm{S})$. There were four replicates of each treatment resulting in a total of 56 pots (Fig. 1).

Experimental set-up

This study was carried out in a non heated glasshouse with open flanks at the Department of Agronomy and Agro-Ecosystem Management, University of Pisa (lat. $43^{\circ} 40^{\prime} \mathrm{N}$, long. $10^{\circ} 19^{\prime}$ E) from May to July 2007. Pots of $30 \mathrm{~cm}$ diameter and $30 \mathrm{~cm}$ height were filled with $10 \mathrm{~kg}$ of autoclaved $\left(80^{\circ} \mathrm{C}\right.$ for $\left.2 \mathrm{~h}\right)$ soil for the $\mathrm{AMF}^{-}$treatment (control). Control pots received $100 \mathrm{ml}$ of a filtrate, obtained by sieving natural soil through a $50 \mu \mathrm{m}$ pore diameter sieve and through Whatman N. 1 paper, to ensure a common microflora for all treatments. Unsterilised natural soil was used in the $\mathrm{AMF}^{+}$treatment to provide indigenous field $\mathrm{AMF}$ populations. All soil was collected at $0-50 \mathrm{~cm}$ depth in a long-term maize cropping systems experiment carried out at the Interdepartmental Centre for Agrienvironmental Research E. Avanzi (CIRAA) of the

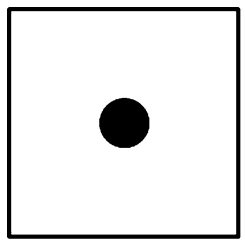

M

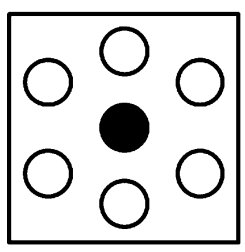

$\mathbf{M}+\mathbf{C}$

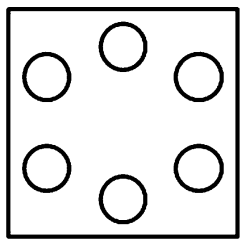

C

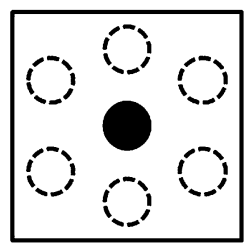

$\mathbf{M}+\mathbf{S}$

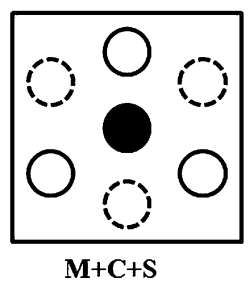

Fig. 1 Schematic representation of experimental pots, showing plant arrangement around each maize plant (where present) in the different competition treatments. Filled circle $=$ Zea mays $(M)$; open continuous circle $=$ Chenopodium album $(C)$; open dotted circle $=$ Solanum nigrum $(S)$. Each combination was repeated three times in each pot
University of Pisa, Italy since 1989. Soil chemical analysis showed a $\mathrm{pH}$ of $8.0,1.70 \%$ organic matter, $0.12 \%$ total nitrogen and $16.8 \mathrm{mg} \mathrm{kg}^{-1}$ available $\mathrm{P}$. Sand, silt and clay content was 49.4, 39.3 and $11.3 \%$ respectively (USDA classification).

Seeds were directly sown into the pots, where crop and weed seedlings thinning was carried out 3 days and 6 days after emergence, respectively, to obtain the planned number of plants pot ${ }^{-1}$. Three maize plants pot $^{-1}$ were left either in monoculture or in mixture with weeds. Maize plants were arranged in such a way that they were equally distant from each other. In maize plus one weed species combinations, 6 weed seedlings surrounding each maize plant were left, thus resulting in 18 weed plants pot ${ }^{-1}$. For the maize plus two weed species combinations, the same final weed density was maintained, thus resulting in three seedlings species ${ }^{-1}$ around each maize plant, in alternate arrangements. The same plant arrangement and density was used for the pots with one weed species or with the two weed species combined, without maize in the centre of the weeds (Fig. 1). Pots were watered regularly to maintain a moisture content between $20 \%$ and $25 \%$ of the soil dry weight. During the whole period of the experiment, random sample pots were weighed prior to water addition to estimate the amount of water lost by evapotranspiration, which was reintegrated through watering until the desired level was reached. Unwanted plant species emerging in the pots were immediately removed. No fertilisation was applied to the pots (Fig. 2).

\section{Data collection and processing}

All parameters were gathered 56 days after sowing. $Z$. mays was in the stem elongation stage, before inflorescence emergence (stage 34-35 of the extended BBCH scale; Lancashire et al. 1991), while C. album (flowering stage; stage 81 of the extended $\mathrm{BBCH}$ scale; Hess et al. 1997) and S. nigrum (fruiting stage; stage 65 of the extended $\mathrm{BBCH}$ scale; Hess et al. 1997) already reached the reproductive stage. Total aboveground biomass for each plant species was determined by cutting plants at the base and oven drying the aboveground biomass for three days at $60^{\circ} \mathrm{C}$ until constant weight. After dry weight determination, plant samples were ground and analysed for total N with the Kjeldahl method (Jones 1991) and for total $\mathrm{P}$ with the molybdate blue ascorbic acid method 

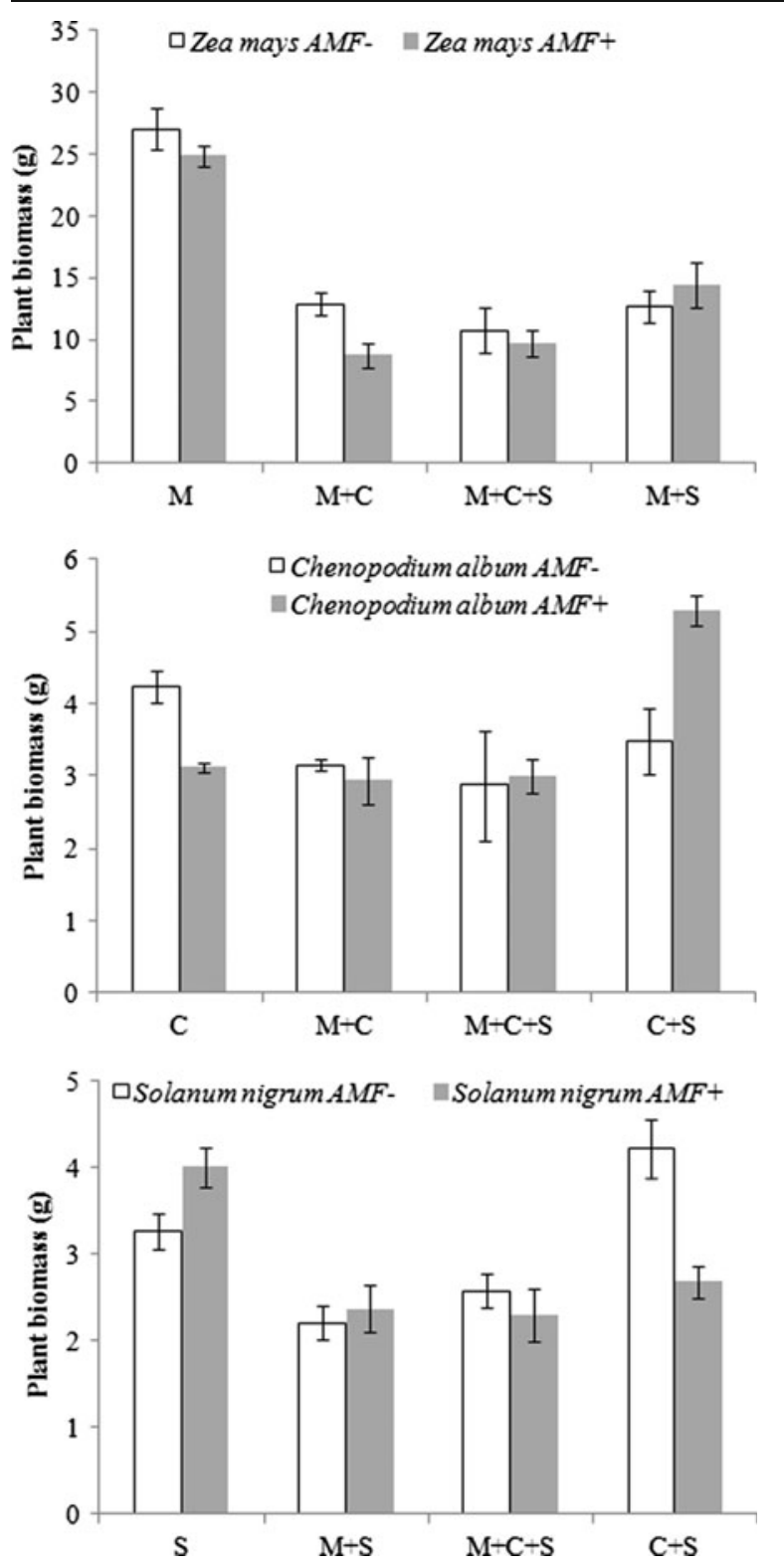

Fig. 2 Above-ground biomass of mycorrhizal $\left(\mathrm{AMF}^{+}\right)$and nonmycorrhizal $\left(\mathrm{AMF}^{-}\right.$) Zea mays, Chenopodium album and Solanum nigrum, grown alone or in competition with one or two of the other species

(Watanabe and Olsen 1965). Total N and P per plant were calculated multiplying $\mathrm{P}$ and $\mathrm{N}$ concentrations by dry weight per plant. Total $\mathrm{N}$ and $\mathrm{P}$ per plant were used to calculate phosphorus (PUE) and nitrogen (NUE) use efficiency, i.e. the biomass produced for each unit of $\mathrm{N}$ or $\mathrm{P}$ uptake (ratio of dry weight/plant $\mathrm{P}$ or $\mathrm{N}$ content). Number of inflorescences for $C$. album and number of fruits for $S$. nigrum were determined on three randomly collected plants pot $^{-1}$. A subsample of known fresh weight was taken from three roots of each plant species, which were washed and analysed for mycorrhizal colonisation following the clearing and staining method, using lactic acid instead of lacto-phenol (Phillips and Hayman 1970) and the gridline intersect method (Giovannetti and Mosse 1980).

Mycorrhizal benefit (MB), percent change in biomass or nutrient content in AM plants (calculated as $\mathrm{MB}=\left(\mathrm{Q}_{\mathrm{AMF}^{+}}{ }^{-}-\mathrm{Q}_{\mathrm{AMF}}^{-}\right) / \mathrm{Q}_{\mathrm{AMF}}{ }^{-}$; Smith and Read 2008) was used to estimate plant species benefit induced by AMF presence in terms of nutrient uptake (nitrogen and phosphorus) and biomass, with or without competition. $Q_{\mathrm{AMF}}{ }^{+}$is the value of parameter $\mathrm{Q}$ in the presence of $\mathrm{AMF}$ and $\mathrm{Q}_{\mathrm{AMF}}{ }^{-}$is the value of the same parameter in the absence of AMF. MB was calculated only on data showing significant differences between $\mathrm{AMF}^{+}$and $\mathrm{AMF}^{-}$values. A zero value of $\mathrm{MB}$ indicates no benefit, while a value $>0$ indicates a benefit from the symbiosis for a given species.

The competitive balance index $\left(\mathrm{C}_{\mathrm{b}}\right.$; Wilson 1988) was used to determine maize competitive ability against C. album or $S$. nigrum or both and the competitive ability of $C$. album against $S$. nigrum in presence or absence of AMF. In the case of interactions among three species, three different $\mathrm{C}_{\mathrm{b}}$ values were computed for maize: one $v s$ both weed species, one $v s$ C. album alone (in the presence of $S$. nigrum) and one $v s S$. nigrum alone (in the presence of C. album). $\mathrm{C}_{\mathrm{b}}$ was computed using the formula:

$\mathrm{C}_{\mathrm{b}}=\log _{\mathrm{e}}\left[\left(\mathrm{W}_{\mathrm{ab}} / \mathrm{W}_{\mathrm{ba}}\right) /\left(\mathrm{W}_{\mathrm{aa}} / \mathrm{W}_{\mathrm{bb}}\right)\right]$

where:

$\mathrm{W}_{\mathrm{aa}} \quad$ weight per plant of species ' $\mathrm{a}$ ' grown in monoculture

$\mathrm{W}_{\mathrm{bb}} \quad$ weight per plant of species ' $\mathrm{b}$ ' grown in monoculture

$\mathrm{W}_{\mathrm{ab}} \quad$ weight per plant of species ' $\mathrm{a}$ ' grown in competition with species ' $b$ '

$\mathrm{W}_{\mathrm{ba}} \quad$ weight per plant of species ' $\mathrm{b}$ ' grown in competition with species ' $a$ '

Positive $C_{b}$ values indicate that species ' $a$ ' has higher competitive ability than species ' $b$ ' in the presence $\left(\mathrm{AMF}^{+}\right)$or absence $\left(\mathrm{AMF}^{-}\right)$of $\mathrm{AMF}$, whereas negative values indicate the opposite. Maize was set as species 'a' in all treatments whereas $C$. 
album was set as species 'a' when grown in association with $S$. nigrum.

\section{Statistical analysis}

Analysis of variance (F test) for two-way randomised complete block design was used to evaluate the effects of AMF presence/absence on maize/weed and weed/weed competitive interactions on plant aboveground biomass, total $\mathrm{N}$ and $\mathrm{P}$ uptake plant ${ }^{-1}$, number of inflorescences plant ${ }^{-1}$ of C. album and number of fruits plant $^{-1}$ of $S$. nigrum. One way ANOVA was performed to compare, within the same plant species, percent AM fungal colonisation among the different competition treatments, after arcsine transformation of data. One way ANOVA was also performed, when significant $P$ values for factors or their interaction were obtained from two-way ANOVA, to compare AMF treatment effect on biomass, $\mathrm{N}$ and $\mathrm{P}$ uptake, number of inflorescences and competitive ability $\left(\mathrm{C}_{\mathrm{b}}\right)$, within the same species and competition treatment, and to compare the same parameters among the
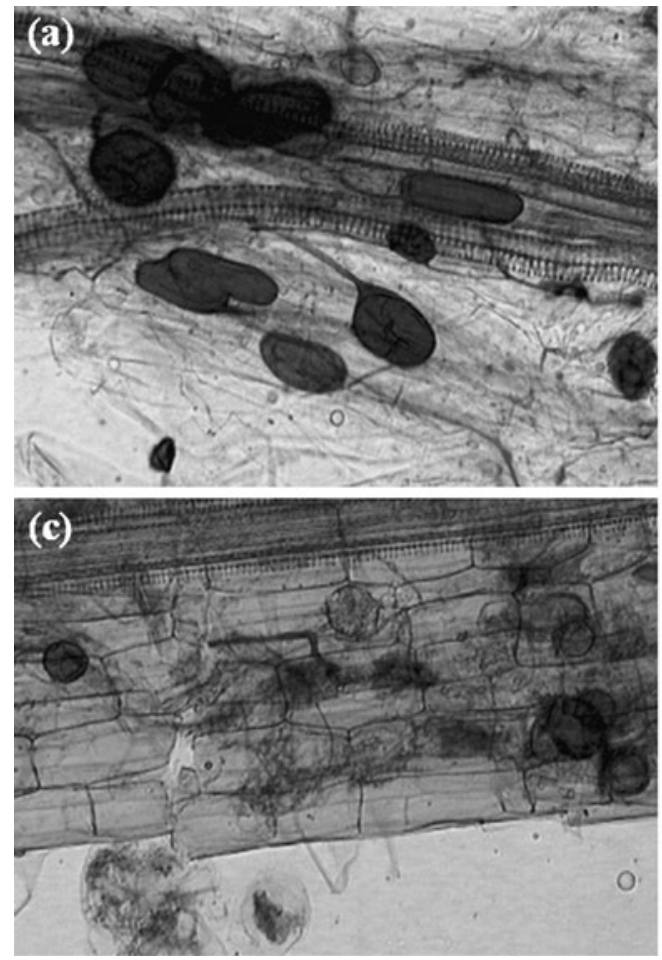

Fig. 3 Representative light micrographs (images) of colonisation patterns by indigenous arbuscular mycorrhizal fungi in trypan blue stained roots of: a, b Chenopodium album, showing different competition treatments, within the same AMF treatment. Among MB data, only those calculated for maize $\mathrm{P}$ uptake, which showed significant differences between $\mathrm{AMF}^{+}$and $\mathrm{AMF}^{-}$in all competition treatments, were submitted to one-way ANOVA.

\section{Results}

Mycorrhizal colonization

As expected, no AMF root colonization was observed in roots of the three plant species in the $\mathrm{AMF}^{-}$treatments. Plant competition influenced AMF colonisation only in the non-host species $C$. album, which showed negligible AMF colonisation in the pure stand and $17-26 \%$ colonised root length in the mixed stands $(\mathrm{df}=3 ; P<0.001)$. Though, mycorrhizal colonization of $C$. album consisted only of intercellular hyphae and vesicles, while arbuscules were never detected (Fig. 3). No significant differences in AMF colonisation among competition
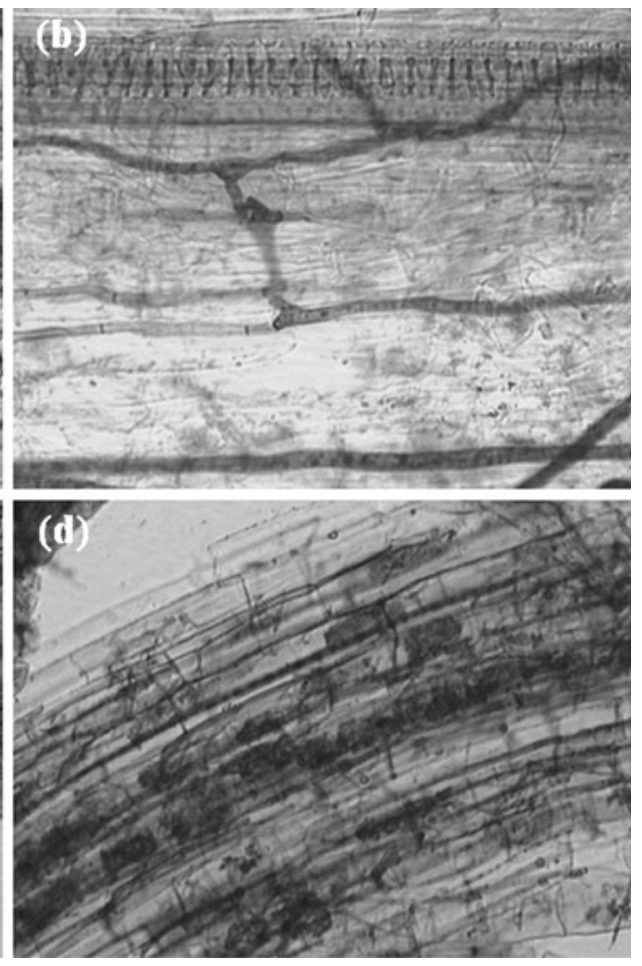

vesicles and intercellular hyphae; c Solanum nigrum and d Zea mays showing intercellular hyphae and arbuscules 
treatments were observed in maize and S. nigrum. However, maize root colonisation was always high, ranging from $56.5 \%$ in the pure stand to $70.2 \%$ in $\mathrm{M}+\mathrm{C}$, whereas colonisation in $\mathrm{S}$. nigrum ranged from $12.6 \%$ in $\mathrm{M}+\mathrm{S}$ to $22.6 \%$ in the pure stand (Table 1).

Above-ground plant biomass and weed fecundity

Two-way ANOVA showed a significant effect of competition treatments only on above-ground biomass of Z. mays and significant interactive effects of competition and mycorrhizal treatment in C. album and S. nigrum (Table 2).

Analysis performed on all eight replicates for each competition treatment, independently on AMF treatment, showed that maize biomass significantly decreased in the presence of competing plant species (by 47.9-60.6\%) (Table 3).

In the pure stand, the $\mathrm{AMF}^{+}$C. album above-ground biomass was lower $(-26 \%)$ than the $\mathrm{AMF}^{-}$C. album one, while it increased by $50 \%$ with respect to $\mathrm{AMF}^{-}$ when $C$. album and $S$. nigrum were grown together (Table 3, Fig. 2). C. album biomass did not significantly vary among remaining competitionxAMF treatments (Table 3).

S. nigrum biomass increased in the presence of AMF in the pure stand $(+21 \%)$, while it was reduced by $36 \%$ in $\mathrm{C}+\mathrm{S}$ (Table 3). In $\mathrm{AMF}^{+}$ treatments, the presence of competing species always resulted in significantly lower $S$. nigrum biomass,

Table 1 Percentage of root length colonised by AMF in Zea mays (M), Chenopodium album (C) and Solanum nigrum (S) grown alone or in competition with one or two of the other plant species

\begin{tabular}{llcl}
\hline Treatment & Zea mays $^{\mathrm{a}}$ & Chenopodium album & Solanum nigrum \\
\hline $\mathrm{M}$ & $56.5 \pm 6.7$ & & \\
$\mathrm{C}$ & & $0.5 \pm 0.4 \mathrm{~b}$ & \\
$\mathrm{~S}$ & & & $22.6 \pm 5.3$ \\
$\mathrm{M}+\mathrm{C}$ & $70.2 \pm 10.5$ & $25.8 \pm 2.7 \mathrm{a}$ & $12.6 \pm 3.3$ \\
$\mathrm{M}+\mathrm{S}$ & $67.2 \pm 4.1$ & & $15.3 \pm 4.6$ \\
$\mathrm{M}+\mathrm{C}+\mathrm{S}$ & $67.5 \pm 5.2$ & $24.3 \pm 4.5 \mathrm{a}$ & $13.1 \pm 1.9$ \\
$\mathrm{C}+\mathrm{S}$ & & $17.3 \pm 4.4 \mathrm{a}$ & \\
\hline
\end{tabular}

${ }^{a}$ Values are means of four replicates \pm SE of the mean. In each column, values followed by different letters are significantly different $(P<0.001)$ with $40 \%, 32 \%$ and $42 \%$ reduction in $\mathrm{M}+\mathrm{S}, \mathrm{C}+\mathrm{S}$ and $\mathrm{M}+\mathrm{C}+\mathrm{S}$, respectively, as compared to the pure stand. In $\mathrm{AMF}^{-}$treatments, biomass of $S$. nigrum in $\mathrm{C}+\mathrm{S}$ was significantly higher than that obtained in the other competition treatments, whereas biomass recorded in the pure stand was not significantly different from the other competitionxAMF treatments (Table 3).

Number of $C$. album inflorescences was not affected by competition treatments, while it was significantly reduced by $\mathrm{AMF}$ presence $(\mathrm{df}=1 ; P=$ 0.002) (Table 4). Neither AMF nor competition affected $S$. nigrum fruit number (data not shown).

$\mathrm{P}$ and $\mathrm{N}$ uptake

AMF and competition treatments influenced plant $\mathrm{P}$ and $\mathrm{N}$ uptake in the different species. Results of twoway ANOVA showed that AMF treatments significantly affected $\mathrm{P}$ uptake in maize and C. album, while it had no effect on their $\mathrm{N}$ uptake. Competition significantly affected $\mathrm{P}$ and $\mathrm{N}$ uptake in all species excepted for P uptake of $C$. album (Table 2). $S$. nigrum also showed a significant AMF $\mathrm{x}$ competition interaction for $\mathrm{N}$ uptake.

Maize $\mathrm{P}$ uptake was significantly higher in $\mathrm{AMF}^{+}$ than in $\mathrm{AMF}^{-}$(from 2.1- to 3.4-fold), across all competition treatments. Furthermore, it was significantly reduced (between $85 \%$ and $127 \%$ ) by the presence of weeds in all competition treatments, except in the binary mixture with $S$. nigrum in the presence of AMF (Table 5). P uptake of C. album was significantly decreased by AMF presence (Table 5). By contrast, P uptake of $S$. nigrum, which was unaffected by AMF presence, was significantly higher (on average $+72 \%$ ) in the pure stand and in the binary mixture with $C$. album than in both combinations with maize (Table 5).

The presence of competing species reduced maize $\mathrm{N}$ uptake independently of AMF treatments, and values obtained in all the competition treatments were significantly lower than the values in the pure stand (Table 6). Although AMF as factor did not significantly affect $\mathrm{N}$ uptake in both weed species (Table 2), a significant interaction between AMF and competition treatments occurred. C. album $\mathrm{N}$ uptake was reduced in the presence of AMF in the pure stand $(-46.5 \%)$ with respect to $\mathrm{AMF}^{-}$values, and increased in the binary mixture with $S$. nigrum (Table 6), 
Table 2 Two-way ANOVA $P$ values for above-ground biomass, $\mathrm{P}$ and $\mathrm{N}$ uptake responses of Zea mays, Chenopodium album and Solanum nigrum to mycorrhizal inoculation (AMF) and plant competition (COMP)
${ }^{\mathrm{a}}$ Factors with significant effect and/or significant interaction were used for oneway/pairwise comparisons

\begin{tabular}{llllll}
\hline Species & Source of variation & Df & Biomass $^{\mathrm{a}}$ & P uptake & N uptake \\
\hline Z. mays & AMF & 1 & 0.201 & 0.004 & 0.481 \\
& COMP & 3 & 0.000 & 0.005 & 0.000 \\
& BLOCK & 3 & 0.868 & 0.310 & 0.325 \\
& AMFxCOMP & 3 & 0.196 & 0.094 & 0.263 \\
& AMFxBLOCK & 3 & 0.454 & 0.325 & 0.460 \\
& COMPxBLOCK & 9 & 0.236 & 0.249 & 0.303 \\
& AMF & 1 & 0.229 & 0.023 & 0.076 \\
& COMP & 3 & 0.008 & 0.552 & 0.030 \\
& BLOCK & 3 & 0.960 & 0.796 & 0.877 \\
& AMFxCOMP & 3 & 0.019 & 0.065 & 0.057 \\
& AMFxBLOCK & 3 & 0.930 & 0.669 & 0.854 \\
& COMPXBLOCK & 9 & 0.563 & 0.196 & 0.599 \\
& AMF & 1 & 0.067 & 0.322 & 0.777 \\
& COMP & 3 & 0.000 & 0.001 & 0.000 \\
& BLOCK & 3 & 0.227 & 0.323 & 0.202 \\
& AMFxCOMP & 3 & 0.000 & 0.194 & 0.006 \\
& AMFxBLOCK & 3 & 0.691 & 0.184 & 0.190 \\
& COMPxBLOCK & 9 & 0.527 & 0.512 & 0.597 \\
\hline
\end{tabular}

showing the largest value among competition treatments (on average $+104.4 \%$ ). On the contrary, $\mathrm{AMF}^{+}$ $S$. nigrum grown with $C$. album showed lower $\mathrm{N}$ uptake $(-30 \%)$ with respect to $\mathrm{AMF}^{-}$. S. nigrum N uptake was affected by competing plants, and values recorded in the $\mathrm{AMF}^{+}$pure stand were significantly higher than in all competition treatments (on average $+90.9 \%$ ). Interestingly, $S$. nigrum N uptake in the $\mathrm{AMF}^{-}$pure stand and in $\mathrm{C}+\mathrm{S}$ were significantly higher (on average $+80.0 \%$ ) than in the combinations which included maize (Table 6).

\section{Mycorrhizal benefit}

Mycorrhizal colonisation provided a benefit to maize in terms of $\mathrm{P}$ uptake, regardless of competition treatment, whereas negative $\mathrm{MB}$ values were observed for above-ground biomass in $\mathrm{M}+\mathrm{C}$ $(-0.32 \pm 0.07$, mean \pm SE of the mean). No MBs were consistently observed for all parameters in the C. album pure stand, whereas a MB of $0.60 \pm 0.23$ (mean \pm SE of the mean) was obtained for biomass when $C$. album was grown in competition with $S$. nigrum. In contrast to $C$. album, $S$. nigrum was benefited by mycorrhizal colonisation in terms of above-ground biomass in the pure stand, and negative values were recorded for $S$. nigrum biomass and $\mathrm{N}$ uptake when grown with $C$. album.

Competitive balance index $\left(\mathrm{C}_{\mathrm{b}}\right)$

Generally, maize was less competitive than either $C$. album or $S$. nigrum in all plant stands, regardless of AMF treatments, as shown by its consistently negative $C_{b}$ values (Table 7). However, AMF colonisation reduced maize competitive ability against $C$. album in the binary mixtures, whilst it significantly increased its competitive ability against S. nigrum.

The competitive relationships between the two weed species were completely reversed by AMF presence: $C$. album was more competitive than $S$. nigrum in the presence of AMF whilst the opposite was observed in the $\mathrm{AMF}^{-}$treatment (Table 7).

\section{PUE and NUE}

PUE and NUE can be considered as the efficiency with which $\mathrm{P}$ and $\mathrm{N}$ are used to produce plant biomass (dry weight). Both in the absence and in the presence of competitors, mycorrhizal inoculation significantly decreased PUE of Z. mays, since the 
Table 3 Above-ground biomass (g plant ${ }^{-1}$ ) of mycorrhizal $\left(\mathrm{AMF}^{+}\right)$and nonmycorrhizal $\left(\mathrm{AMF}^{-}\right)$Zea mays $(\mathrm{M})$, Chenopodium album (C) and Solanum nigrum (S), grown alone or in competition with one or two of the other species

\begin{tabular}{|c|c|c|c|}
\hline \multirow[t]{2}{*}{ Treatment } & \multicolumn{3}{|l|}{ Zea mays } \\
\hline & $\mathrm{AMF}^{+}$ & $\mathrm{AMF}^{-}$ & All data \\
\hline M & $24.9 \pm 0.8$ & $27.0 \pm 1.7$ & $25.95 \pm 0.95 \mathrm{a}$ \\
\hline $\mathrm{M}+\mathrm{C}$ & $8.7 \pm 1.0$ & $12.9 \pm 0.9$ & $10.81 \pm 1.00 \mathrm{~b}$ \\
\hline $\mathrm{M}+\mathrm{S}$ & $14.4 \pm 1.8$ & $12.7 \pm 1.3$ & $13.52 \pm 1.06 \mathrm{~b}$ \\
\hline $\mathrm{M}+\mathrm{C}+\mathrm{S}$ & $9.7 \pm 1.1$ & $10.8 \pm 1.9$ & $10.21 \pm 1.02 \mathrm{~b}$ \\
\hline$P$ value $^{\mathrm{a}}$ & & & $<0.001$ \\
\hline Treatment & \multicolumn{2}{|c|}{ Chenopodium album } & Solanum nigrum \\
\hline $\mathrm{C} \mathrm{AMF}^{-}$ & \multicolumn{2}{|c|}{$4.2 \pm 0.2 \mathrm{ab}$} & \\
\hline $\mathrm{C} \mathrm{AMF}^{+}$ & \multicolumn{2}{|c|}{$3.1 \pm 0.1 \mathrm{~b}$} & \\
\hline $\mathrm{M}+\mathrm{C} \mathrm{AMF}^{-}$ & \multicolumn{2}{|c|}{$3.2 \pm 0.1 \mathrm{~b}$} & \\
\hline $\mathrm{M}+\mathrm{C} \mathrm{AMF}^{+}$ & \multicolumn{2}{|l|}{$2.9 \pm 0.3 \mathrm{~b}$} & \\
\hline $\mathrm{C}+\mathrm{S} \mathrm{AMF}^{-}$ & \multicolumn{2}{|c|}{$3.5 \pm 0.5 \mathrm{~b}$} & $4.2 \pm 0.3 \mathrm{a}$ \\
\hline $\mathrm{C}+\mathrm{S} \mathrm{AMF}^{+}$ & \multicolumn{2}{|c|}{$5.3 \pm 0.2 \mathrm{a}$} & $2.7 \pm 0.1 \mathrm{~b}$ \\
\hline $\mathrm{M}+\mathrm{C}+\mathrm{S} \mathrm{AMF}^{-}$ & \multicolumn{2}{|l|}{$2.9 \pm 0.8 \mathrm{~b}$} & $2.6 \pm 0.2 \mathrm{~b}$ \\
\hline $\mathrm{M}+\mathrm{C}+\mathrm{S} \mathrm{AMF}^{+}$ & \multicolumn{2}{|c|}{$3.0 \pm 0.2 \mathrm{~b}$} & $2.3 \pm 0.3 \mathrm{~b}$ \\
\hline $\mathrm{S} \mathrm{AMF}^{-}$ & & & $3.3 \pm 0.2 \mathrm{ab}$ \\
\hline $\mathrm{S} \mathrm{AMF}^{+}$ & & & $4.0 \pm 0.2 \mathrm{a}$ \\
\hline $\mathrm{M}+\mathrm{S} \mathrm{AMF}^{-}$ & & & $2.2 \pm 0.2 \mathrm{~b}$ \\
\hline $\mathrm{M}+\mathrm{S} \mathrm{AMF}^{+}$ & & & $2.4 \pm 0.3 \mathrm{~b}$ \\
\hline$P$ value & 0.001 & & $<0.001$ \\
\hline
\end{tabular}

For Zea mays, means of four replicates \pm SE of the mean $\left(\mathrm{AMF}^{+}\right.$and $\left.\mathrm{AMF}^{-}\right)$and means of all eight replicates $\pm \mathrm{SE}$ of the mean are reported

${ }^{\text {a }} P$ values refer to results of one way ANOVA comparing the different treatments. In the columns, values followed by different letters are significantly different $(P \leq 0.05)$

increase in $\mathrm{P}$ content of mycorrhizal plants was not followed by a similar increase in biomass (Table 8). $S$. nigrum PUE was not affected by mycorrhizal colonisation, except when the host weed grew in the presence of C. album: in such a treatment a significant reduction in $\mathrm{AMF}^{+} S$. nigrum biomass with respect to $\mathrm{AMF}^{-}$, without differences in $\mathrm{P}$ content, significantly decreased PUE. The opposite behaviour was observed for the non-host weed C. album, in which PUE was significantly enhanced by AMF in the presence of $S$. nigrum, since the same $\mathrm{P}$ content resulted in an increase of C. album biomass of $127.1 \%$, compared with non inoculated plants (Table 8). No significant differences in PUE were observed among competition treatments, both in $\mathrm{AMF}^{+}$and $\mathrm{AMF}^{-}$plants, for $Z$. mays and $S$. nigrum, whereas $\mathrm{AMF}^{+}$C. album showed significant differences between plants grown with $Z$. mays $(\mathrm{M}+\mathrm{C})$ or with both competitors $(\mathrm{M}+\mathrm{C}+\mathrm{S})$ and those grown with $S$. nigrum $(\mathrm{C}+\mathrm{S})$ (Table 8).

Values of NUE (data not shown) were never significantly affected by competition or by mycorrhizal inoculation, except for $\mathrm{AMF}^{+}$and $\mathrm{AMF}^{-}$C. album grown alone $(\mathrm{df}=1 ; \mathrm{F}=31.36 ; P=0.021)$.

\section{Discussion}

In this work, plant growth responses and competitive interactions were studied in an experimental system, where an AMF host crop (maize) and two weeds, one host ( $S$. nigrum) and one non-host (C. album) were grown together in the presence or absence of a natural AMF community. Results showed that AMF altered the competitive relationships between co-occurring plant species with different mycorrhizal status (host/ non-host).

\section{Mycorrhizal colonization}

Colonized root length of maize and $S$. nigrum was unaltered by competition treatments while that of $C$. album was negligible in the pure stand, and increased significantly when grown with the host plants maize or $S$. nigrum. It is interesting to note that C. album, belonging to a family known as non-host, showed intraradical colonization with hyphae and vesicles, but without any arbuscule. Colonization of non-host

Table 4 Number of inflorescences plant ${ }^{-1}$ produced by mycorrhizal $\left(\mathrm{AMF}^{+}\right)$and nonmycorrhizal $\left(\mathrm{AMF}^{-}\right)$Chenopodium album (C) grown alone or in competition with Zea mays (M) or Solanum nigrum (S) or both

\begin{tabular}{lll}
\hline Treatment & $\mathrm{AMF}^{+\mathrm{a}}$ & $\mathrm{AMF}^{-}$ \\
\hline $\mathrm{C}$ & $18.0 \pm 8.5$ & $71.8 \pm 10.9$ \\
$\mathrm{C}+\mathrm{S}$ & $43.5 \pm 8.7$ & $82.5 \pm 7.0$ \\
$\mathrm{M}+\mathrm{C}$ & $36.8 \pm 14.4$ & $69.0 \pm 26.2$ \\
$\mathrm{M}+\mathrm{C}+\mathrm{S}$ & $33.5 \pm 9.8$ & $40.3 \pm 9.1$ \\
All data $^{\mathrm{b}}$ & $32.94 \pm 5.3^{\mathrm{c}}$ & $65.88 \pm 7.9$ \\
\hline
\end{tabular}

${ }^{a}$ Values are means of four replicates $\pm \mathrm{SE}$ of the mean

${ }^{\mathrm{b}}$ Values are means of 16 replicates $\pm \mathrm{SE}$ of the mean

${ }^{\mathrm{c}}$ Values significantly different $(P=0.002)$ between $\mathrm{AMF}^{+}$and $\mathrm{AMF}^{-}$ 
Table 5 Phosphorus uptake (mg plant $\left.{ }^{-1}\right)$ in mycorrhizal $\left(\mathrm{AMF}^{+}\right)$and non mycorrhizal $\left(\mathrm{AMF}^{-}\right)$Zea mays (M), Chenopodium album (C) and Solanum nigrum (S), grown alone or in competition with one or two of the other species

\begin{tabular}{|c|c|c|c|c|c|c|c|}
\hline \multirow[t]{2}{*}{ Treatment } & \multicolumn{2}{|l|}{ Zea mays ${ }^{\mathrm{a}}$} & \multicolumn{2}{|c|}{ Chenopodium album } & \multicolumn{3}{|c|}{ Solanum nigrum } \\
\hline & $\mathrm{AMF}^{+}$ & $\mathrm{AMF}^{-}$ & $\mathrm{AMF}^{+}$ & $\mathrm{AMF}^{-}$ & $\mathrm{AMF}^{+}$ & $\mathrm{AMF}^{-}$ & All data ${ }^{c}$ \\
\hline M & $34.9 \pm 3.9 \mathrm{~b}^{\mathrm{b}}$ & $15.2 \pm 3.1 \mathrm{~b}$ & & & & & \\
\hline $\mathrm{C}$ & & & $4.2 \pm 0.6$ & $9.7 \pm 0.5$ & & & \\
\hline $\mathrm{S}$ & & & & & $6.1 \pm 1.1$ & $4.1 \pm 0.2$ & $5.1 \pm 0.6 \mathrm{a}$ \\
\hline $\mathrm{M}+\mathrm{C}$ & $15.6 \pm 2.3 \mathrm{a}^{\mathrm{b}}$ & $7.5 \pm 0.7 \mathrm{a}$ & $5.3 \pm 0.8$ & $6.4 \pm 0.3$ & & & \\
\hline $\mathrm{M}+\mathrm{S}$ & $27.5 \pm 5.7 \mathrm{ab}^{\mathrm{b}}$ & $8.2 \pm 1.3 \mathrm{a}$ & & & $3.0 \pm 0.3$ & $2.4 \pm 0.2$ & $2.7 \pm 0.2 \mathrm{~b}$ \\
\hline $\mathrm{M}+\mathrm{C}+\mathrm{S}$ & $18.9 \pm 1.1 \mathrm{a}^{\mathrm{b}}$ & $6.7 \pm 1.3 \mathrm{a}$ & $5.2 \pm 0.6$ & $6.6 \pm 2.1$ & $3.2 \pm 0.5$ & $3.6 \pm 0.2$ & $3.4 \pm 0.3 \mathrm{~b}$ \\
\hline $\mathrm{C}+\mathrm{S}$ & & & $7.4 \pm 1.0$ & $7.2 \pm 0.9$ & $5.7 \pm 1.1$ & $5.3 \pm 0.6$ & $5.4 \pm 1.0 \mathrm{a}$ \\
\hline All data ${ }^{c}$ & & & $5.5 \pm 0.4^{\mathrm{b}}$ & $7.5 \pm 0.6$ & & & \\
\hline$P$ value & 0.01 & 0.03 & 0.01 & & & & $<0.001$ \\
\hline
\end{tabular}

${ }^{\text {a }}$ Values are means of four replicates $\pm \mathrm{SE}$ of the mean

${ }^{\mathrm{b}}$ Values are significantly different $(P \leq 0.05)$ between $\mathrm{AMF}^{+}$and $\mathrm{AMF}^{-}$within the same plant species. $P$ values refer to results of one way ANOVA comparing the different competition treatments or $(C$. album) mycorrhizal treatments on all data

${ }^{\mathrm{c}}$ Values are means of eight (S. nigrum) and 16 (C. album) replicates \pm SE of the mean. In columns, values followed by different letters are significantly different $(P \leq 0.05)$ among competition treatments

plants belonging to Chenopodioideae, Brassicaceae and Amaranthaceae was previously reported (Miller 1979; Allen et al. 1989; Giovannetti et al. 1994; DeMars 1996; Rydlova and Vosatka 2001; Orlowska et al. 2002; Regvar et al. 2003), although data on the occurrence of arbuscules and on AMF effects on plant growth were inconsistent (Williams et al. 1974; Lovera and Cuenca 1996; Regvar et al. 2003; Vatovec et al. 2005). Ocampo (1980) and Stejskalova (1990) observed mycorrhizal colonization of C. album when grown together with maize and onion (both AMF hosts), a phenomenon described as the 'nurseplant effect'. In this work, established extraradical mycelial networks originating from host roots (maize or $S$. nigrum) might have spread in the soil and colonized the root system of nearby $C$. album plants (Malcova et al. 2001; Sykorova et al. 2003; Enkhtuya et al. 2005). Accordingly, Puschel et al. (2007) showed colonization of non-host plants when grown in the presence of pre-existing extraradical mycelial networks, while no colonization was observed when only spores were used as inoculum. It is of interest to note that tomato mutants unable to establish AMF symbioses when inoculated with germinated spores, where colonised in the presence of symbiotic mycelium originating from mycorrhizal roots of a host plant growing nearby (David-Schwartz et al. 2003).
Plant responses in the pure stand

Mycorrhizal symbiosis enhanced maize $\mathrm{P}$ uptake with no related increase in biomass or $\mathrm{N}$ uptake, which turned out in reduced PUE. These results are consistent with AMF role in enhanced $\mathrm{P}$ uptake by host plants even if overall biomass or $\mathrm{N}$ uptake remain unaffected (Landis et al. 2005; Reynolds et al. 2005; Smith and Read 2008; Smith and Smith 2011). In the literature, the absence of mycorrhizal plant benefits has been commonly attributed to large C drain by the fungal symbionts (Fitter 1991). Furthermore, whole field soil inoculum without any $\mathrm{N}$ fertilization, utilised in our experiment, could have caused nitrogen immobilization, resulting in no growth response in $\mathrm{AMF}^{+}$maize. Nevertheless, important non-nutritional mycorrhizal benefits, due to changes in water relations, phytohormone levels and carbon assimilation have been reported (Smith and Read 2008). Interestingly, AMF mediated $P$ uptake was also active in those plants, known as 'nonresponsive hosts', where no increases in $\mathrm{P}$ content and biomass were observed (Li et al. 2008; Grace et al. 2009).

In the pure stand, significantly larger plant biomass was detected in $\mathrm{AMF}^{+} S$. nigrum, whereas $\mathrm{AMF}^{+} C$. album showed decreased $\mathrm{P}$ content and biomass, as compared to $\mathrm{AMF}^{-}$, consistently with previous data 
Table 6 Nitrogen uptake (mg plant $\left.{ }^{-1}\right)$ in mycorrhizal $\left(\mathrm{AMF}^{+}\right)$ and non mycorrhizal (AMF ${ }^{-}$) Zea mays (M), Chenopodium album (C) and Solanum nigrum (S), grown alone or in competition with one or two of the other species

\begin{tabular}{|c|c|c|c|}
\hline \multirow[t]{2}{*}{ Treatment } & \multicolumn{3}{|l|}{ Zea mays } \\
\hline & $\mathrm{AMF}^{+}$ & $\mathrm{AMF}^{-}$ & All data \\
\hline M & $15.3 \pm 0.5$ & $17.2 \pm 2.4$ & $16.31 \pm 1.19 \mathrm{~b}$ \\
\hline $\mathrm{M}+\mathrm{C}$ & $5.5 \pm 0.5$ & $7.0 \pm 0.4$ & $6.28 \pm 0.43 \mathrm{a}$ \\
\hline $\mathrm{M}+\mathrm{S}$ & $8.6 \pm 1.3$ & $6.8 \pm 0.5$ & $7.72 \pm 0.72 \mathrm{a}$ \\
\hline $\mathrm{M}+\mathrm{C}+\mathrm{S}$ & $6.1 \pm 0.8$ & $6.5 \pm 0.6$ & $6.32 \pm 0.44 \mathrm{a}$ \\
\hline$P$ value & & & $<0.001$ \\
\hline Treatment & \multicolumn{2}{|c|}{ Chenopodium album } & Solanum nigrum \\
\hline $\mathrm{C} \mathrm{AMF}^{-}$ & \multicolumn{2}{|c|}{$4.3 \pm 0.3 \mathrm{ab}$} & \\
\hline $\mathrm{C} \mathrm{AMF}^{+}$ & \multicolumn{2}{|c|}{$2.3 \pm 0.4 \mathrm{bc}$} & \\
\hline $\mathrm{M}+\mathrm{C} \mathrm{AMF}^{-}$ & \multicolumn{2}{|c|}{$2.7 \pm 0.1 \mathrm{abc}$} & \\
\hline $\mathrm{M}+\mathrm{C} \mathrm{AMF}^{+}$ & \multicolumn{2}{|c|}{$2.5 \pm 0.3 \mathrm{abc}$} & \\
\hline $\mathrm{C}+\mathrm{S} \mathrm{AMF}^{-}$ & \multicolumn{2}{|c|}{$3.4 \pm 0.4 \mathrm{abc}$} & $3.7 \pm 0.3 \mathrm{ab}$ \\
\hline $\mathrm{C}+\mathrm{S} \mathrm{AMF}^{+}$ & \multicolumn{2}{|c|}{$4.6 \pm 0.3 \mathrm{a}$} & $2.5 \pm 0.2 \mathrm{bc}$ \\
\hline $\mathrm{M}+\mathrm{C}+\mathrm{S} \mathrm{AMF}{ }^{-}$ & \multicolumn{2}{|c|}{$2.9 \pm 0.9 \mathrm{abc}$} & $2.1 \pm 0.2 \mathrm{c}$ \\
\hline $\mathrm{M}+\mathrm{C}+\mathrm{S} \mathrm{AMF}^{+}$ & \multicolumn{2}{|c|}{$2.0 \pm 0.6 \mathrm{c}$} & $2.1 \pm 0.2 \mathrm{c}$ \\
\hline $\mathrm{S} \mathrm{AMF}^{-}$ & & & $3.5 \pm 0.2 \mathrm{ab}$ \\
\hline $\mathrm{S} \mathrm{AMF}^{+}$ & & & $4.2 \pm 0.3 \mathrm{a}$ \\
\hline $\mathrm{M}+\mathrm{S} \mathrm{AMF}^{-}$ & & & $1.9 \pm 0.1 \mathrm{c}$ \\
\hline $\mathrm{M}+\mathrm{S} \mathrm{AMF}^{+}$ & & & $2.0 \pm 0.3 \mathrm{c}$ \\
\hline$P$ value ${ }^{\mathrm{a}}$ & 0.003 & & $<0.001$ \\
\hline
\end{tabular}

For Zea mays, means of four replicates \pm SE of the mean $\left(\mathrm{AMF}^{+}\right.$and $\left.\mathrm{AMF}^{-}\right)$and means of all eight replicates $\pm \mathrm{SE}$ of the mean are reported

${ }^{\text {a }} P$ values refer to results of one way ANOVA comparing the different treatments. In the columns, values followed by different letters are significantly different $(P \leq 0.05)$

on non-host plants (Grime et al. 1987; van der Heijden et al. 1998; Ruotsalainen and Aikio 2004). Interestingly, Jordan et al. (2000) reported that AMF inoculation reduced C. album growth rate by $80 \%$. So far, the actual mechanism underlying such a phenomenon is still unclear: production of allelopathic metabolites by AMF, reducing root hair production and possibly affecting non-host plant direct nutrient uptake, has been hypothesized (Francis and Read 1994; Cameron 2010; Facelli et al. 2010). Other authors suggested that AMF colonisation of non-host plant roots may lead to parasitic interactions involving plant defence responses and root cell and/or plant death (Allen et al. 1989; Giovannetti and Lioi 1990).

AMF significantly reduced $C$. album inflorescence production in the pure stand, compared to the $\mathrm{AMF}^{-}$ treatment, consistently with previous data (Sanders and Koide 1994). Our results suggest that low P and $\mathrm{N}$ uptake by $\mathrm{AMF}^{+}$C. album might be involved in the reduced production of inflorescences.

Maize-weed and weed-weed competitive interactions

Competition with weeds significantly decreased maize $\mathrm{N}$ and $\mathrm{P}$ uptake and biomass accumulation, although $\mathrm{AMF}^{+}$maize consistently showed larger $\mathrm{P}$ uptake in all competitive treatments, with respect to $\mathrm{AMF}^{-}$. Both in the absence and in the presence of competitors, PUE of $\mathrm{AMF}^{+}$maize decreased as compared to $\mathrm{AMF}^{-}$plants, since $\mathrm{P}$ content enhancement was not paralleled by plant biomass increase. Growth reduction in the presence of competing plants was often observed in mycorrhizal plants (Hartnett et al. 1993; Kytoviita et al. 2003; Schroeder-Moreno and Janos 2008; Hausmann and Hawkes 2009), possibly due to physiological changes induced by AMF in host roots, affecting their ability to acquire nutrients via the direct pathway, independently from AMF (Facelli et al. 2010). In our work the addition of $\mathrm{N}$ could have changed the outcome of competition, allowing mycorrhizal maize plants to positively respond to AMF inoculation, possibly enhancing their competitivity towards weeds. Our data suggest that $S$. nigrum low $\mathrm{P}$ uptake in $\mathrm{M}+\mathrm{S}$ treatment may facilitate maize, which is better able to

Table 7 Competitive balance index $\left(\mathrm{C}_{\mathrm{b}}\right)$ for Zea mays $(\mathrm{M})$ against each of the weed species in the binary or tertiary competition treatments, and for Chenopodium album (C) against Solanum nigrum (S) in the binary or tertiary species mixtures in the presence $\left(\mathrm{AMF}^{+}\right)$or absence $\left(\mathrm{AMF}^{-}\right)$of mycorrhizae, and corresponding $P$ values

\begin{tabular}{lll}
\hline Competition treatment & $\mathrm{AMF}^{+}$ & $\mathrm{AMF}^{-}$ \\
\hline $\mathrm{M}$ vs C & $-0.98(P=0.07)$ & -0.45 \\
$\mathrm{M}$ vs C $[+\mathrm{S}]^{\mathrm{a}}$ & $-0.91(P=0.35)$ & -0.48 \\
$\mathrm{M}$ vs S & $-0.02(P=0.05)$ & -0.37 \\
$\mathrm{M}$ vs S $[+\mathrm{C}]^{\mathrm{b}}$ & $-0.39(P=0.26)$ & -0.72 \\
$\mathrm{M}$ vs C+S & $-0.55(P=0.89)$ & -0.59 \\
$\mathrm{C}$ vs S & $0.93(P=0.01)$ & -0.47 \\
$\mathrm{C}$ vs S $[+\mathrm{M}]^{\mathrm{c}}$ & $0.52(P=0.04)$ & -0.24 \\
\hline
\end{tabular}

${ }^{\text {a }} Z$. mays vs $C$. album (in the presence of $S$. nigrum)

${ }^{\mathrm{b}} Z$. mays vs $S$. nigrum (in the presence of $C$. album)

${ }^{\mathrm{c}} C$. album vs $S$. nigrum (in the presence of $Z$. mays) 
Table 8 Phosphorus use efficiency (PUE, mg aboveground biomass/mg P taken up) in Zea mays (M), Chenopodium album (C) and Solanum nigrum $(\mathrm{S})$ in the different competition treatments, in the presence $\left(\mathrm{AMF}^{+}\right)$or absence $\left(\mathrm{AMF}^{-}\right)$of mycorrhizae

\begin{tabular}{|c|c|c|c|c|c|c|}
\hline \multirow[t]{2}{*}{ Treatment } & \multicolumn{2}{|l|}{ Zea mays ${ }^{\mathrm{a}}$} & \multicolumn{2}{|l|}{ Chenopodium album } & \multicolumn{2}{|l|}{ Solanum nigrum } \\
\hline & $\mathrm{AMF}^{+}$ & $\mathrm{AMF}^{-}$ & $\mathrm{AMF}^{+}$ & $\mathrm{AMF}^{-}$ & $\mathrm{AMF}^{+}$ & $\mathrm{AMF}^{-}$ \\
\hline M & $745.04 \pm 100.21$ & $2058.79 \pm 458.93$ & & & & \\
\hline $\mathrm{C}$ & & & $2547.27 \pm 507.98 \mathrm{ab}$ & $1843,32 \pm 137.06$ & & \\
\hline S & & & & & $731,84 \pm 147.78$ & $799,16 \pm 67.73$ \\
\hline $\mathrm{M}+\mathrm{C}$ & $578.06 \pm 63.03$ & $1773.96 \pm 196.86$ & $1691.11 \pm 279.63 b$ & $1566,48 \pm 92.26 \mathrm{a}$ & & \\
\hline $\mathrm{M}+\mathrm{S}$ & $552.79 \pm 54.16$ & $1590.38 \pm 106.64$ & & & $786,36 \pm 59.30$ & $938,54 \pm 149.76$ \\
\hline $\mathrm{M}+\mathrm{C}+\mathrm{S}$ & $513.65 \pm 57.46$ & $1650.34 \pm 137.82$ & $1716.37 \pm 146.50 \mathrm{~b}$ & $1257,16 \pm 283.54 \mathrm{a}$ & $744,31 \pm 56.23$ & $706,96 \pm 27.48$ \\
\hline $\mathrm{C}+\mathrm{S}$ & & & $4015.95 \pm 509.69 \mathrm{a}^{\mathrm{b}}$ & $1768,21 \pm 446.52 \mathrm{a}$ & $506,41 \pm 58.07$ & $818,78 \pm 73.13$ \\
\hline All data & $597.38 \pm 39.1^{\mathrm{b}}$ & $1768.37 \pm 127.1$ & & & & \\
\hline$P$ & & & 0.001 & & & \\
\hline
\end{tabular}

\footnotetext{
${ }^{a}$ In columns, values followed by different letters are significantly different $(P \leq 0.05)$ among competition treatments. $P$ value refer to results of one way ANOVA comparing the different competition treatments

${ }^{\mathrm{b}}$ Values significantly different between $\mathrm{AMF}^{+}$and $\mathrm{AMF}^{-}$within the same plant species
}

benefit from mycorrhiza-mediated $\mathrm{P}$ uptake, as compared to the other competition treatments, whereas maize plant benefit, competitivity and $\mathrm{P}$ uptake data were the lowest in mycorrhizal treatments when maize grew together with the non-host weed C. album. Such findings indicate that AMF are able to affect the competitive ability of maize, depending on the mycorrhizal status of the competing weeds.

The two weed species tested showed differential responses to $\mathrm{AMF}$ : $\mathrm{AMF}^{+}$and $\mathrm{AMF}^{-} S$. nigrum showed similarly reduced biomass and $\mathrm{N}$ uptake when grown in competition treatments, although its performances with $C$. album $(\mathrm{C}+\mathrm{S})$ significantly declined in the presence of AMF. Interestingly, negative performances of $\mathrm{AMF}^{+} S$. nigrum in the presence of the non-host $C$. album were concurrent with $C$. album larger $\mathrm{N}$ uptake and biomass production, confirming AMF ability to shift competitive relationships between host and non-host plants. Accordingly, $\mathrm{N}$ capture by Brassica napus, a nonhost species, was found to increase in the presence of AMF, particularly when grown in competition with the host Plantago lanceolata (Hodge 2003).

In the presence of AMF, the non-host weed $C$. album appeared not to change its ability to acquire $\mathrm{P}$, according to its inability to host intracellular fungal structures involved in P transfer to host roots. Nevertheless, it was shown that $\mathrm{P}$ translocation to plants by
AMF occurred in plant mutants where only intercellular fungal structures were developed (Manjarrez et al. 2011).

Unravelling the mechanisms by which mycorrhizal fungi may alter plant performance in interspecific competition is extremely difficult, due to the differences in nutrient acquisition and growth strategies of the competing plants (Smith and Read 2008; Facelli et al. 2010). The results obtained in this work with $S$. nigrum and C. album mixture may depend on the relative mycotrophy of competitors, consistently with data from mixed communities: negative effects were detected on dominating plants grown with low mycotrophic competitors, whose competitive ability was enhanced by AMF (Grime et al. 1987). Accordingly, the detrimental effects of AMF on nutrient uptake and productivity of non-hosts occurring in the pure stand are not necessarily shown when the same species are grown in competitive conditions. Moreover, the establishment of non-mycorrhizal controls in sterilised soil plus natural soil filtrate, although widely used (Smith and Smith 1981; Ceccarelli et al. 2010; Asghari and Cavagnaro 2011), may cause indirect effects on plant growth, as compared to mycorrhizal treatments set up in unsterile soil (Koide and $\mathrm{Li}$ 1989). Such difficulty reduces the possibility of drawing conclusions predictive of plant behaviour in field conditions. 
The potential role of AMF as agroecosystem engineers has only recently been tackled (Jordan et al. 2000; Rinaudo et al. 2009; Cameron 2010), despite the obvious importance of AMF in plant competitive relationships. AMF role in crop-weed and weed-weed interactions, involving plants with different competitive abilities and mycorrhizal status, is still not well understood. Experiments with a limited number of interacting plant species are necessary to unravel step by step (and case by case) the mechanisms underlying AMF effects in crop-weed and weed-weed competitive relationships.

\section{References}

Allen MF, Allen EB, Friese CF (1989) Responses of the nonmycotrophic plant Salsola kali to invasion by vesiculararbuscular mycorrhizal fungi. New Phytol 111:45-49

Asghari HR, Cavagnaro TR (2011) Arbuscular mycorrhizas enhance plant interception of leached nutrients. Funct Plant Biol 38:219-226

Ayres RL, Gange AC, Aplin DM (2006) Interactions between arbuscular mycorrhizal fungi and intraspecific competition affect size, and size inequality, of Plantago lanceolata L. J Ecol 94:285-294

Bárberi P, Mazzoncini M (2001) Changes in weed community composition as influenced by cover crop and management system in continuous corn. Weed Sci 49:491-499

Cameron DD (2010) Arbuscular mycorrhizal fungi as (agro) ecosystem engineers. Plant Soil 333:1-5

Ceccarelli N, Curadi M, Martelloni L, Sbrana C, Picciarelli P, Giovannetti M (2010) Mycorrhizal colonization impacts on phenolic content and antioxidant properties of artichoke leaves and flower heads two years after field transplant. Plant Soil 335:311-323

David-Schwartz R, Gadkar V, Wininger S, Bendov R, Galili G, Levy AA, Kapulnik Y (2003) Isolation of a premycorrhizal infection (pmi2) mutant of tomato, resistant to arbuscular mycorrhizal fungal colonization. Mol Plant Microbe Interact 16:382-388

Davis AS, Renner KA, Gross KL (2005) Weed seedbank and community shifts in a long-term cropping systems experiment. Weed Sci 53:296-306

DeMars BG (1996) Vesicular-arbuscular mycorrhizal status of spring ephemerals in two Ohio forests. Ohio J Sci 96:97-99

Eissenstat DM, Newman EI (1990) Seedling establishment near large plants: effects of vesicular-arbuscular mycorrhizas on the intensity of plant competition. Funct Ecol 4:95-99

Enkhtuya B, Poschl M, Vosatka M (2005) Native grass facilitates mycorrhizal colonisation and $\mathrm{P}$ uptake of tree seedlings in two anthropogenic substrates. Water Air Soil Pollut 166:217-236

Facelli E, Smith SE, Facelli JM, Christophersen HM, Smith FA (2010) Underground friends or enemies: model plants help to unravel direct and indirect effects of arbuscular mycorrhizal fungi on plant competition. New Phytol 185:1050-1061
Fitter AH (1991) Costs and benefits of mycorrhizas: implications for functioning under natural conditions. Experientia 47:350-355

Francis R, Read DJ (1994) The contributions of mycorrhizal fungi to the determination of plant community structure. Plant Soil 159:11-25

Francis R, Read DJ (1995) Mutualism and antagonism in the mycorrhizal symbiosis, with special reference to impacts on plant community structure. Can J Bot 73:S1301-S1309

Giovannetti M, Fortuna P, Citernesi AS, Morini S, Nuti MP (2001) The occurrence of anastomosis formation and nuclear exchange in intact arbuscular mycorrhizal networks. New Phytol 151:717-724

Giovannetti M, Lioi L (1990) The mycorrhizal status of Arbutus unedo in relation to compatible and incompatible fungi. Can J Bot 68:1239-1244

Giovannetti M, Mosse B (1980) An evaluation of techniques for measuring vesicular-arbuscular mycorrhizal infection in roots. New Phytol 84:489-500

Giovannetti M, Sbrana C, Avio L, Strani P. (2004) Patterns of belowground plant interconnections established by means of arbuscular mycorrhizal networks. New Phytol 164:175-181

Giovannetti M, Sbrana C, Logi C (1994) Early processes involved in host recognition by arbuscular mycorrhizal fungi. New Phytol 126:703-709

Grace EJ, Smith FA, Smith SE (2009) Deciphering the arbuscular Mmycorrhizal pathway of $\mathrm{P}$ uptake in non-responsive plant species. In: Azcón-Aguilar C, Barea JM, Gianinazzi S, Gianinazzi-Pearson V (eds) Mycorrhizas: functional processes and ecological impact. Springer, Berlin

Grime JP, Mackey JML, Hillier SH, Read DJ (1987) Floristic diversity in a model system using experimental microcosms. Nature 328:420-422

Hamel C, Furlan V, Smith DL (1992) Mycorrhizal effects on interspecific plant competition and nitrogen transfer in legume-grass mixtures. Crop Sci 32:991-996

Hartnett DC, Hetrick BAD, Wilson GWT, Gibson DJ (1993) Mycorrhizal influence on intraspecific and interspecific neighbour interactions among co-occurring prairie grasses. J Ecol 81:787-795

Hausmann NT, Hawkes CV (2009) Plant neighborhood control of arbuscular mycorrhizal community composition. New Phytol 183:1188-1200

Heppell KB, Shumway DL, Koide RT (1998) The effect of Mycorrhizal infection of Abutilon theophrasti on competitiveness of offspring. Funct Ecol 12:171-175

Hess M, Barralis G, Bleiholder H, Buhr L, Eggers Th, Hack H, Stauss R (1997) Use of the extended BBCH-scalegeneral for the description of the growth stages of monoand dicotyledonous weed species. Weed Res 37:433441

Hodge A (2003) N capture by Plantago lanceolata and Brassica napus from organic material: the influence of spatial dispersion, plant competition and an arbuscular mycorrhizal fungus. J Exp Bot 54:2331-2342

Johnson NC (1998) Responses of Salsola kali and Panicum virgatum to mycorrhizal fungi, phosphorus and soil organic matter: implications for reclamation. J Appl Ecol 35:86-94

Jones JB Jr (1991) Kjeldahl method for nitrogen determination. Micro-Macro, Athens 
Jordan NR, Zhang J, Huerd S (2000) Arbuscular-mycorrhizal fungi: potential roles in weed management. Weed Res 40:397-410

Koide RT, Li M (1989) Appropriate controls for vesiculararbuscular mycorrhiza research. New Phytol 111:3544

Koide RT, Lu X (1992) Mycorrhizal infection of wild oats: maternal effects on offspring growth and reproduction. Oecologia 90:218-226

Koide RT, Lu X (1995) On the cause of offspring superiority conferred by mycorrhizal infection of Abutilon theophrasti. New Phytol 131:435-441

Kytoviita MM, Vestberg M, Tuom J (2003) A test of mutual aid in common mycorrhizal networks: Established vegetation negates benefit in seedlings. Ecology 84:898-906

Lancashire PD, Bleiholder H, Langelüddecke P, Stauss R, van den Boom T, Weber E, Witzenberger A (1991) A uniform decimal code for growth stages of crops and weeds. Ann Appl Biol 119:561-601

Landis FC, Gargas A, Givnish TJ (2005) The influence of arbuscular mycorrhizae and light on Wisconsin (USA) sand savanna understories 2 Plant competition. Mycorrhiza 15:555-562

Li HY, Smith FA, Dickson S, Holloway RE, Smith SE (2008) Plant growth depressions in arbuscular mycorrhizal symbioses: not just caused by carbon drain? New Phytol 178:852-862

Lovera M, Cuenca G (1996) Arbuscular mycorrhizal infection in Cyperaceae and Gramineae from natural, disturbed and restored savannas in La Gran Sabana, Venezuela. Mycorrhiza 6:111-118

Malcova R, Albrechtova J, Vosatka M (2001) The role of the extraradical mycelium network of arbuscular mycorrhizal fungi on the establishment and growth of Calamagrostis epigejos in industrial waste substrates. Appl Soil Ecol 18:129-142

Manjarrez M, Christophersen HM, Smith SE, Smith FA (2011) Cortical colonisation is not an absolute requirement for phosphorus transfer to plants in arbuscular mycorrhizas formed by Scutellospora calospora in a tomato mutant: evidence from physiology and gene expression. Func Plant Biol 37:1132-1142

Miller RM (1979) Some occurrences of vesicular-arbuscular mycorrhiza in natural and disturbed ecosystems of the Red Desert. Can J Bot 57:619-623

Moora M, Zobel M (1996) Effect of arbuscular mycorrhiza on inter- and intraspecific competition of two grassland species. Oecologia 108:79-84

Muthukumar T, Udaiyan K, Karthikeyan A, Manian S (1997) Influence of native endomycorrhiza, soil flooding and nurse plant on mycorrhizal status and growth of purple nutsedge (Cyperus rotundus L). Agric Ecosyst Environ 61:51-58

Ocampo JA (1980) Effect of crop rotations involving host and non-host plants on vesicular-arbuscular mycorrhizal infection of host plant. Plant Soil 56:283-291

Orlowska E, Zubek S, Jurkiewicz A, Szarek LG, Turnau K (2002) Influence of restoration on arbuscular mycorrhiza of Biscutella laevigata L (Brassicaceae) and Plantago lanceolata L (Plantaginaceae) from calamine spoil mounds. Mycorrhiza 12:153-160
Phillips JM, Hayman DS (1970) Improved procedure for clearing roots and staining parasites and vesiculararbuscular mycorrhizal fungi for rapid assessment of infection. Trans Br Mycol Soc 55:158-161

Puschel D, Rydlova J, Vosatka M (2007) The development of arbuscular mycorrhiza in two simulated stages of spoilbank succession. Appl Soil Ecol 35:363-369

Regvar M, Vogel K, Irgel N, Wraber T, Hildebrandt U, Wilde P, Bothe H (2003) Colonization of pennycresses (Thlaspi spp) of the Brassicaceae by arbuscular mycorrhizal fungi. J Plant Physiol 160:615-626

Rejon A, Garcia-Romera I, Ocampo JA, Bethlenfalvay GJ (1997) Mycorrhizal fungi influence competition in a wheat-ryegrass association treated with the herbicide diclofop. Appl Soil Ecol 7:51-57

Reynolds HL, Hartley AE, Vogelsang KM, Bever JD, Schultz PA (2005) Arbuscular mycorrhizal fungi do not enhance nitrogen acquisition and growth of old-field perennials under low nitrogen supply in glasshouse culture. New Phytol 167:869-880

Rinaudo V, Bàrberi P, Giovannetti M, van der Heijden MGA (2009) Mycorrhizal fungi suppress aggressive agricultural weeds. Plant Soil 333:7-20

Ruotsalainen AL, Aikio S (2004) Mycorrhizal inoculum and performance of nonmycorrhizal Carex bigelowii and mycorrhizal Trientalis europaea. Botany 82:443-449

Rydlova J, Vosatka M (2001) Associations of dominant plant species with arbuscular mycorrhizal fungi during vegetation development on coal mine spoil banks. Folia Geobot 36:85-97

Sanders IR, Koide RT (1994) Nutrient acquisition and community structure in co-occurring mycotrophic and non-mycotrophic old-field annuals. Funct Ecol 8:77-84

Scheublin TR, Van Logtestijn RSP, van der Heijden MGA (2007) Presence and identity of arbuscular mycorrhizal fungi influence competitive interactions between plant species. J Ecol 95:631-638

Schroeder-Moreno MS, Janos DP (2008) Intra- and interspecific density affects plant growth responses to arbuscular mycorrhizas. Botany-Botanique 86:1180-1193

Schussler A, Schwarzott D, Walker C (2001) A new fungal phylum, the Glomeromycota: phylogeny and evolution. Mycol Res 105(Part 12):1413-1421

Smith SE, Read DJ (2008) Mycorrhizal simbiosis. Academic, New York

Smith FA, Smith SE (1981) Mycorrhizal infection and growth of Trifolium subterraneum: use of sterilized soil as a control treatment. New Phytol 88:299-309

Smith SE, Smith FA (2011) Roles of arbuscular mycorrhizas in plant nutrition and growth: new paradigms from cellular to ecosystem scales. Annu Rev Plant Biol 62:227-250

Stejskalova H (1990) The role of mycorrhizal infection in weed-crop interactions. Agric Ecosyst Environ 29:415419

Sykorova Z, Rydlova J, Vosatka M (2003) Establishment of mycorrhizal symbiosis in Gentiana verna. Folia Geobot 38:177-189

van der Heijden MGA, Klironomos JN, Ursic M, Moutoglis P, Streitwolf-Engel R, Boller T, Wiemken A, Sanders IR (1998) Mycorrhizal fungal diversity determines plant 
biodiversity, ecosystem variability and productivity. Nature 396:69-72

van der Putten WH, Peters BAM (1997) How soil-borne pathogens may affect plant competition. Ecology 78:1785-1795

Vatovec C, Jordan N, Huerd S (2005) Responsiveness of certain agronomic weed species to arbuscular mycorrhizal fungi. Renew Agr Food Syst 20:181-189

Watanabe FS, Olsen SR (1965) Test of an ascorbic acid method for determining phosphorus in water and $\mathrm{NaHCO}_{3}$ extracts from soil. Soil Sci Soc Am J 29:677
Watkinson AR, Freckleton RP (1997) Quantifying the impact of arbuscular mycorrhiza on plant competition. J Ecol $85: 541-545$

West HM (1996) Influence of arbuscular mycorrhizal infection on competition between Holcus lanatus and Dactylis glomerata. J Ecol 84:429-438

Williams SE, Aldon AG, Earl F (1974) Growth of Atriplex canescens (Pursh) Nutt improved by formation of vesiculararbuscular mycorrhizae. Soil Sci Soc Am J 38:962

Wilson JB (1988) Shoot competition and root competition. J Appl Ecol 25:279-296 